\title{
PEMBUATAN PROGRAM SISTEM INFORMASI \\ PENANGGULANGAN HAMA DAN PENYAKIT TANAMAN \\ BAGI PENYULUH PERTANIAN
}

\section{DEVELOPMENT PROGRAM INFORMATION SYSTEM PLANT PEST AND DISEASE PREVENTION FOR AGRICULTURAL EXTENSION}

\author{
Jusuf Wahyudi' ${ }^{1)}$, Herlina ${ }^{2)}$, Hesti Nur'aini' ${ }^{3)}$ \\ ${ }^{1}$ Program Studi Teknik Informatika Fakultas Ilmu Komputer UNIVED \\ ${ }^{2}$ Program Studi Agribisnis Fakultas Pertanian UNIVED \\ ${ }^{3}$ Program Studi Teknologi Pertanian Fakultas Pertanian UNIVED
}

\begin{abstract}
ABSTRAK
Pelaksanaan bimbingan dan penyuluhan tentan informasi hama dan penyakit tanaman serta penanggulangannya adalah kondisi wilayah kelompok-kelompok tani. Selain itu, jumlah tenaga penyuluh pertanian yang ada khususnya di Provinsi Bengkulu cukup banyak baik tenaga penyuluh tetap (PNS), kontrak maupun penyuluh swadaya tetapi masih memerlukan penambahan pengetahuan tentang pengendalian hama dan penyakit tanaman. Tujuan khusus dari penelitian ini adalah terbentuknya perangkat lunak (Software) yang memiliki fungsi sebagai bahan ajar bagi para penyuluh yang akan terjun ke lapangan dalam proses bimbingan dan penyuluhan penanggulangan hama dan penyakit tanaman tropika. Sehingga pengetahaun yang dimikili para penyuluh dapat senantiasa terbarukan, sesuai dengan perkembangan informasi tentang penanggulangan hama dan penyakit tanaman. Perangkat lunak yang dihasilkan nantinya akan diserahkan masternya secara cuma-cuma kepada pemerintah melalui badan koordinasi penyuluh (Bakorluh) Provinsi Bengkulu sebagai pilot project dari program sistem informasi manajemen pengendalian hama dan penyakit tanaman. Sedangkan proses pelatihan pemakaian program akan diselenggarakan dengan mengikuti jadwal yang diatur oleh Bakorlah setelah mendapat petunjuk dari pemerintah provinsi. Berdasarkan pada kenyataan di atas, maka yang perlu mendapat perhatian nantinya adalah tingkat kelengkapan data dan informasi yang berkenaan dengan persoalan berbagai hama, berbagai penyakit yang menyerang pada berbagai tanaman dan sekaligus tata cara penanggulangannya. Sehingga pemutakhiran data dan informasinya pun secara terus menerus sangat diperlukan untuk dibarukan (updatable) dan disampaikan kepada para petani yang tergabung melalui keloimpokkelompok tani. Program yang sedang dibuat ini telah menunjukkan banyaknya kemudahan yang akan didapat oleh para penyuluh karena berbagai kebutuhan informasi sehubungan dengan hama dan penyakit tanaman yang dibutuhkan para petani nantinya dengan muda dijelaskan oleh penyuluh. Program ini setelah sempurna meskipun versi alfa, sudah mampu mengakomodir kebutuhan berbagai informasi bagi petani maupun penyuluh. Penyempurnaan yang perlu dilakukan adalah dalam bentuk perbaikan data mutakhir tentang hama dan penyakit tanaman yang dapat saja berubah karena perubahan kemampuan hama dan penyakit serta kemungkinan timbulnya varian baru dari hama dan penyakit suatu tanaman yang sudah pasti memerlukan cara penanggulangan yang baru pula.
\end{abstract}

Kata kunci : Sistem Informasi, Penanggulangan Hama dan Penyakit, Penyuluh Pertanian 


\section{ABSTRACT}

Extension of plant pests and diseases and tackling has been done by the trainers during the many difficulties and obstacles because of the location and the diversity of the problems faced. The limitations of distance and knowledge of the extension in their duties greatly affect the productivity results. To assist the government in resolving the issue, the need for a computer program information system that can be accessed in the location extension. The program should be able to address various issues of plant pests and diseases as well as mitigation. Program in accordance with the specific needs of course to be built specifically Similarly, in this case the program is made by using the BASIC programming language that has a lot of ability in terms of process automation and published in several editions (versions) according to the development of information of pests and plant diseases as well as mitigation. Techniques used in the preparation of the information systems program using the concept of Waterfalls Sommerville (2001: 45). Methods of data collection related to plant pests and diseases and tackling done by search and literature. The research result obtained is an application program that is easy to administer instructor and has been tested in the presence of pests at random extension. The test results were obtained, that the program has been good and it can be applied but need continued improvement to the development of pest control and plant diseases.

Keywords: hama, penyakit, tanaman, sistem informasi

\section{PENDAHULUAN}

Kemajuan teknologi informasi dewasa ini sudah sangat pesat yang dapat dirasakan oleh berbagai kalangan, baik dalam bentuk kemudahan mendapatkan informasi melalui berbagai situs maupun jejaring sosial maupun blog. Dimana berbagai informasi dapat dicari dengan mudah seperti pada berbagai mesin pencari (search engine) seperti Google, Bing, Opera dan sebagainya. Selain itu, kemudahan mendapatkan berbagai informasi melalui papan-papan informasi, perpustakaan menetap maupun keliling, media cetak serta media elektronik seperti radio dan televisi.

Namun patut disayangkan, bahwa kemudahan memperoleh informasi tersebut semuanya lebih memusat atau terpusatkan di kota-kota. Sedangkan di daerah-daerah pelosok, untuk mendapatkan satu macam informasi saja harus menunggu beberapa lama atau bahkan tidak ada sama sekali. Keadaan yang paling menyedihkan adalah tidak adanya jasa internet untuk mencari atau menelusuri informasi yang sangat dibutuhkan oleh para petani di pelosokpelosok. Sehingga kehadiran penyuluh yang memiliki pengetahuan yang luas sangat diharapkan dalam memberikan bimbingan dan penyuluan tentang hama dan penyakit tanaman serta penanggulangan.

Untuk menambah wawasan tentang berbagai hama dan penyakit pada 
berbagai tanaman kepada para penyuluh, perlu adanya pelatihan tambahan serta laptop yang telah dilengkapi dengan perangkat lunak yang dibuat khusus untuk menampilkan sistem informasi manajemen penanggulangan hama dan penyakit tanaman.

\section{METODE PENELITIAN}

\section{Bagan Alir Penelitian}

Model peraancangan suatu sistem Sommerville (2001:45) mengungkapkan bahwa terdapat beberapa model yang dapat digunakan, yakni :

1. Model Waterfalls (Air Terjun), yaitu model perancangan sistem yang menggambarkan tahapan lengkap dari mulai Analisis dan Definisi Persyaratan, Perancangan sistem dan perangkat lunak, implementasi dan pengujian unit, integrasi dan pengujian sistem, operasi dan pemeliharaan. Adapun masingmasing tahap tersebut dapat dijelaskan sebagai berikut :

\section{a. Analisis dan Definisi}

Persyaratan, yaitu pelayanan, batasan dan tujuan ditentukan melalui konsultasi dengan user sistem. Persyaratan ini kemudian didefinisikan secara rinci dan berfungsi sebagai spesifikasi sistem.

\section{b. Perancangan Sistem dan}

Perangkat Lunak, yaitu proses perancangan sistem membagi persyaratan dalam sistem perangkat lunak. Kegiatan ini menentukan arsitektur sistem secara keseluruhan.

\section{c. Implementasi dan Pengujian} unit, yaitu perancangan perangkat lunak yang direalisasikan sebagai rangkaian program atau unit program. Pengujian unit melibatkan verifikasi setiap unit apakah telah memenuhi spesifikasinya.

\section{d. Integrasi dan Pengujian Sistem,} yaitu unit program atau program individu diintegrasi dan diuji sebagai sistem yang lengkap untuk menjamin bahwa persyaratan sistem telah dipenuhi dan setelah memenuhi kemudian program dikirim kepada pelanggan untuk dilakukan pengujian oleh pelanggan apakah sesuai dengan keinginan yang telah ditentukan oleh pelanggan..

\section{e. Operasi dan Pemeliharaan,} yaitu merupakan fase siklus hidup yang paling lama, karena sistem diinstall, dipakai dan terus dipakai oleh pengguna yang dalam hal ini adalah para penyuluh sampai 
ditemukan faktor koreksi yang perlu dilakukan perbaikan.

Untuk menyederhanakan pemahaman model Waterfalls tersebut, berikut ini disajikan gambar dari siklus hidup model dimaksud seperti gambar 1 .

2. Model Pengembangan Evolusioner, yaitu model yang berdasarkan pada ide dan diimplemetasi awal kemudian ditawarkan kepada pelanggan untuk dieksplorasi dan dikomentari. Kemudian dilakukan revisi bertahap sesuai dengan keinginan user.

3. Model Pengembangan Formal, yaitu model yang mendasarkan konsepnya mirip dengan model Waterfalls, tetapi pengembangannya didasarkan pada transformasi matematis dari spesifikasi sistem.

4. Model Pengembangan Berorientasi Pemakaian Ulang, yaitu model yang mendasarkan konsepnya pada daur ulang terhadap program yang memiliki kemiripan dengan spesifikasi sistem yang diharapkan oleh pelanggan. Model jenis ini dapat digunakan apabila program yang akan didaur ulang tersebut mendapat persetujuan pemilik program sah sebelumnya untuk dimodifikasi.

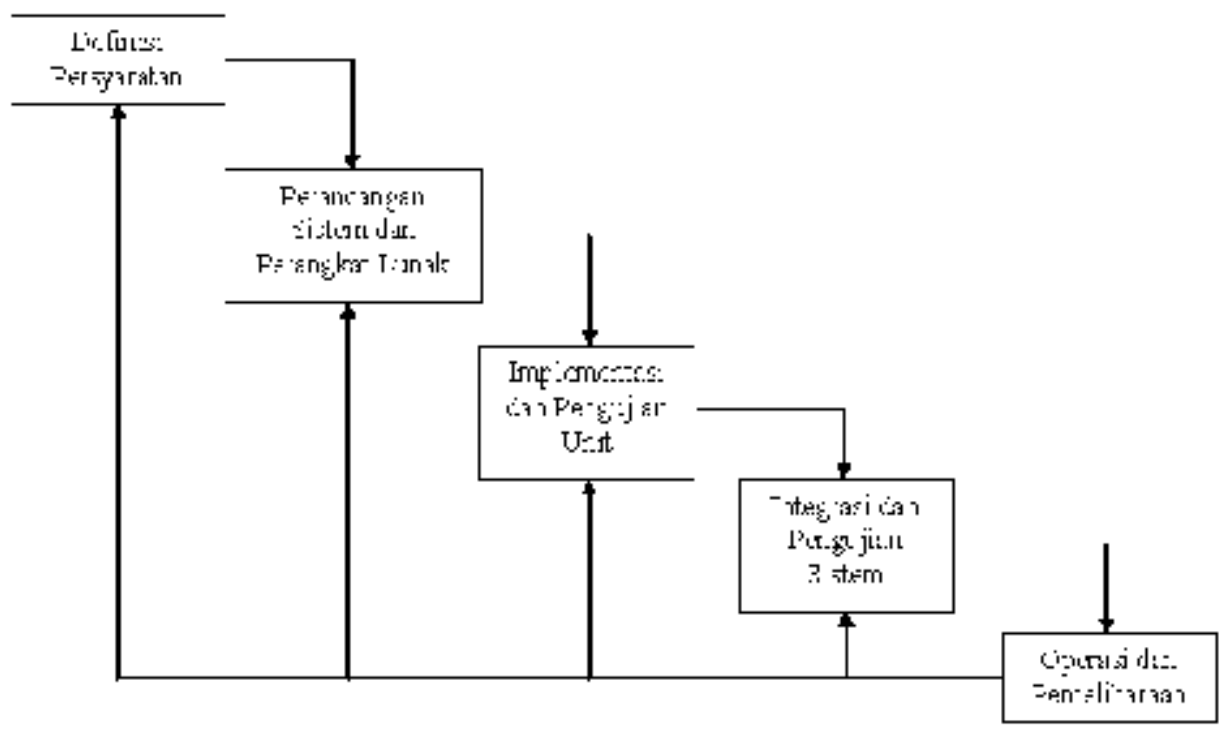

Gambar 1. Siklus Hidup Model Waterfalls 


\section{Pengujian Sistem}

Setelah program selesai dibangun dan dilakukan ujicoba (trial and error), untuk menjaga kinerja program dan akuntabilitasnya, selanjutnya dilakukan pengujian sistem dengan beberapa tahap uji, yakni :

\section{Pengujian White Box (Glass Box),} yaitu pengujian terhadap rancangan yang menggunakan struktur kontrol design procedural untuk mendapatkan test case. Pengujian ini dilakukan untuk memberikan jaminan terhadap jalur independent pada suatu modul minimal telah digunakan satu kali. Kemudian logis pada pemilihan kondisi True atau False dan menggunakan data internal untuk menjaga validitasnya.

2. Pengujian Basis Path, yaitu pengujian yang memungkinkan disain test case mengukur kompleksitas logis dari disain prosedural dan menggunakannya sebagai pedoman untuk menentukan basis set dari jalur eksekusi.

3. Pengujian Struktur Kontrol, yaitu pengujian yang memungkinkan untuk melakukan pengujian kondisi, aliran data dan perulangan (looping).

\section{Pengujian Black-Box atau Pengujian Behavioral atau}

Pengujian Partisi, yaitu pengujian yang berfokus pada persyaratan fungsional perangkat lunak. Selain itu adalah memungkinkan untuk mendapatkan serangkaian input yang sepenuhnya menggunakan semua persyaratan fungsional.

\section{HASIL DAN PEMBAHASAN}

Penelitian ini dilakukan dalam dua bagian, yakni bagian survey atau pengamatan serta bagian pembuatan program. Survey pendahuluan telah mulai dilakukan sejak bulan Januari 2015, hal ini dilakukan bertujuan untuk mengumpulkan berbagai informasi dan data yang berkenaan dengan keadaan yang nyata pada suatu daerah. Oleh sebab itu, maka perlu dilakukan pengumpulan berbagai informasi penting di lapangan dalam hal hama dan penyakit tanaman.

Pelaksanaan survey yang dilakukan adalah mengikuti jangkauan wilayah kabupaten yang ada, yakni semakin jauh jangkauan perjalanan survey maka lokasi yang dituju terpusat hanya pada satu tempat tujuan. Sedangkan jika jangkauan wilayah yang akan diempuh cukup dekat, maka pelaksanaan survey diusahakan mampu mencakup dua lokasi tujuan. Dimana pelaksanaannya dilakukan setiap awal bulan agar tidak mengganggu 
aktifitas akademik yang lain. Kemudian data dan informasi yang didapat dikumpulkan untuk kemudian direkam untuk menjadi bahan masukan pada uji coba program.

Selain pelaksanaan survey ke lapangan, dilakukan juga wawancara dan konsultasi baik ke Bakorluh maupun ke BPTPH Provinsi Bengkulu. Yang mana peneliti langsung melakukan komunikasi dengan para penyuluh. Alasan wawancara secara langsung dengan para penyuluh adalah karena para penyuluh lah yang berhadapan secara langsung dengan para petani dan menerima berbagai pertanyaan dan usulan sehubungan keluhan petani tentang hama dan penyakit tanaman yang ada di daerah binaannya.

Tahap utama dari penelitian ini adalah pembuatan program sesuai dengan topic utama judul penelitian. Dimana untuk mendapatkan program yang baik tentunya telah dipersiapkan, disusun serta dilakukan uji coba terkendali dan luwes dalam penggunaannya. Selain itu, program yang telah dibuat nantinya harus mampu melayani jika akan dilakukan perubahan dan perbaikan; baik perubahan terhadap system secara umum ataupun peubahan pada nilai-nilai, besaranbesaran, gambar-gambar, prosedurprosedur serta fungsi-fungsi maupun modul-modul yang ada.

Contoh tampilan awal program yang sedang dibangun dapat dilihat pada gambar 2, 3 dan 4 .

Dari contoh tampilan gambar yang ada, data maupun informasi yang dibutuhkan dalam menyelesaikan program ini sangat besar dan banyak serta keragamannya pun juga mengikuti kebutuhan daerah produksi pertanian. Apalagi jika dilihat pada menu yang tersedia, maka dapat dipastikan akan memerlukan masa penyelesaian terhadap program yang lama.

Tahap berikutnya yang diharapkan adalah ujicoba secara terus menerus (pengujian dengan metode black box) sampai benarbenar tidak ditemukan lagi permasalahan terhadap coding yang telah diketik. 


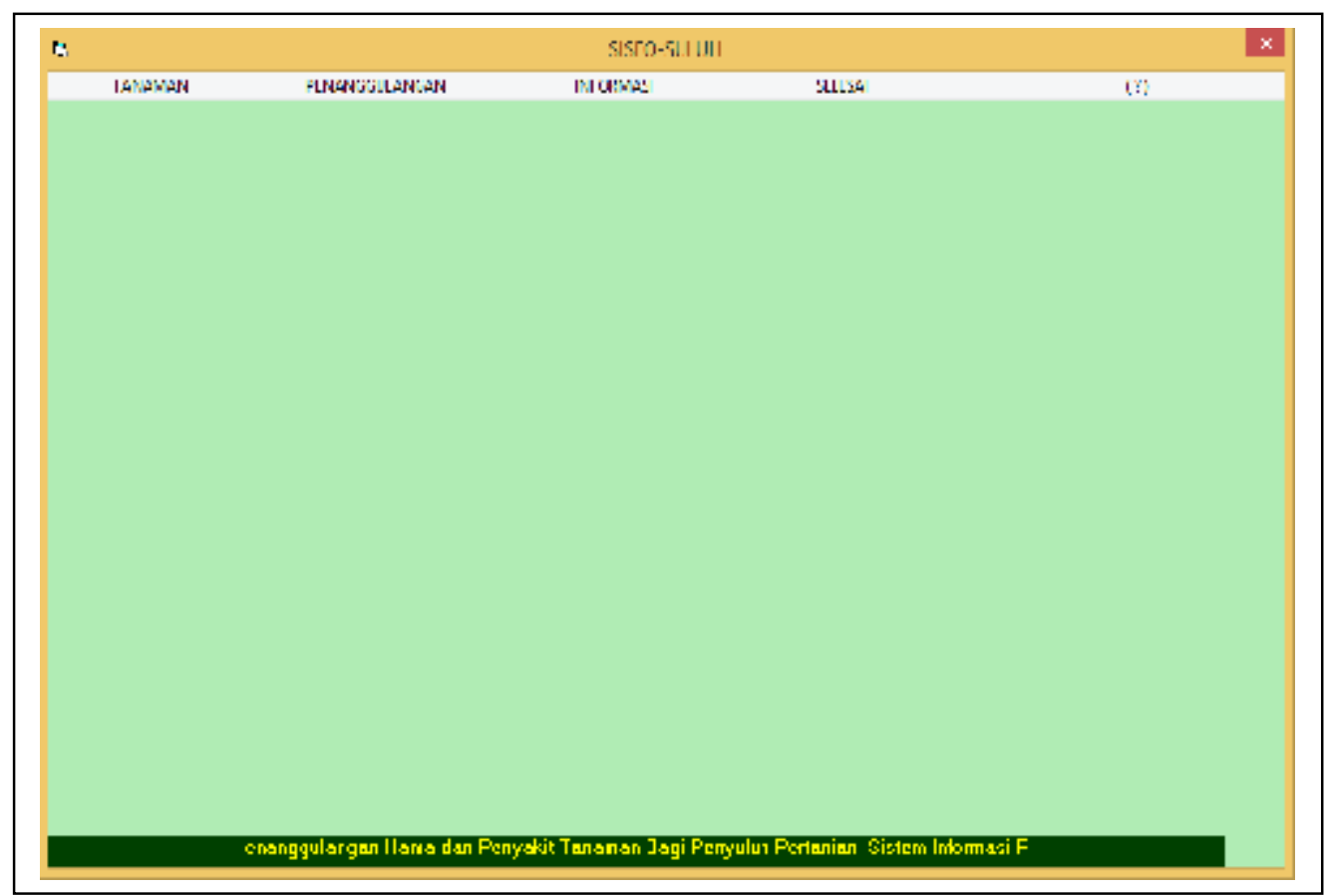

Gambar 2. Tampilan Menu Utama Program

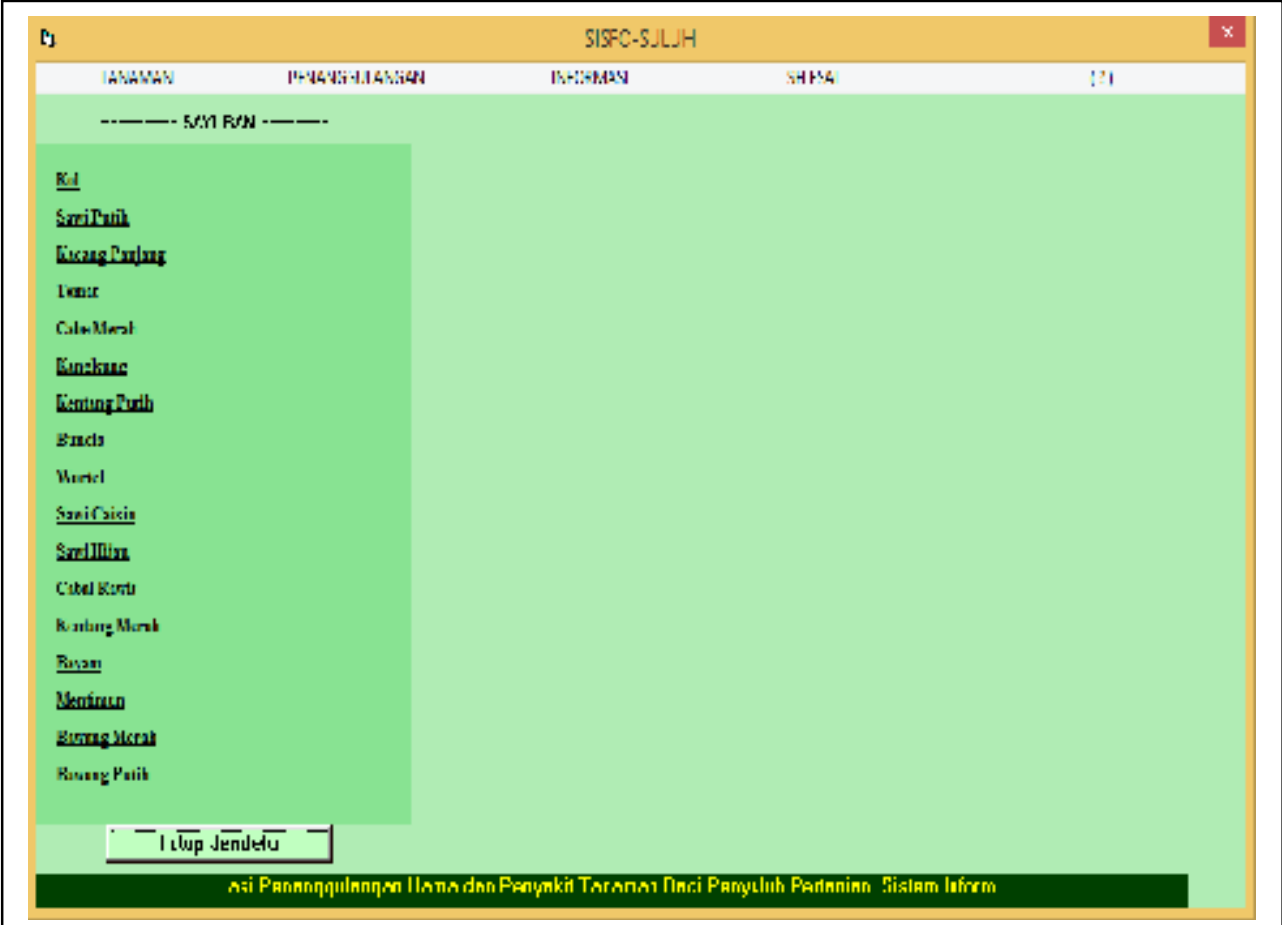

Gambar 3. Tampilan Submenu Tanaman 


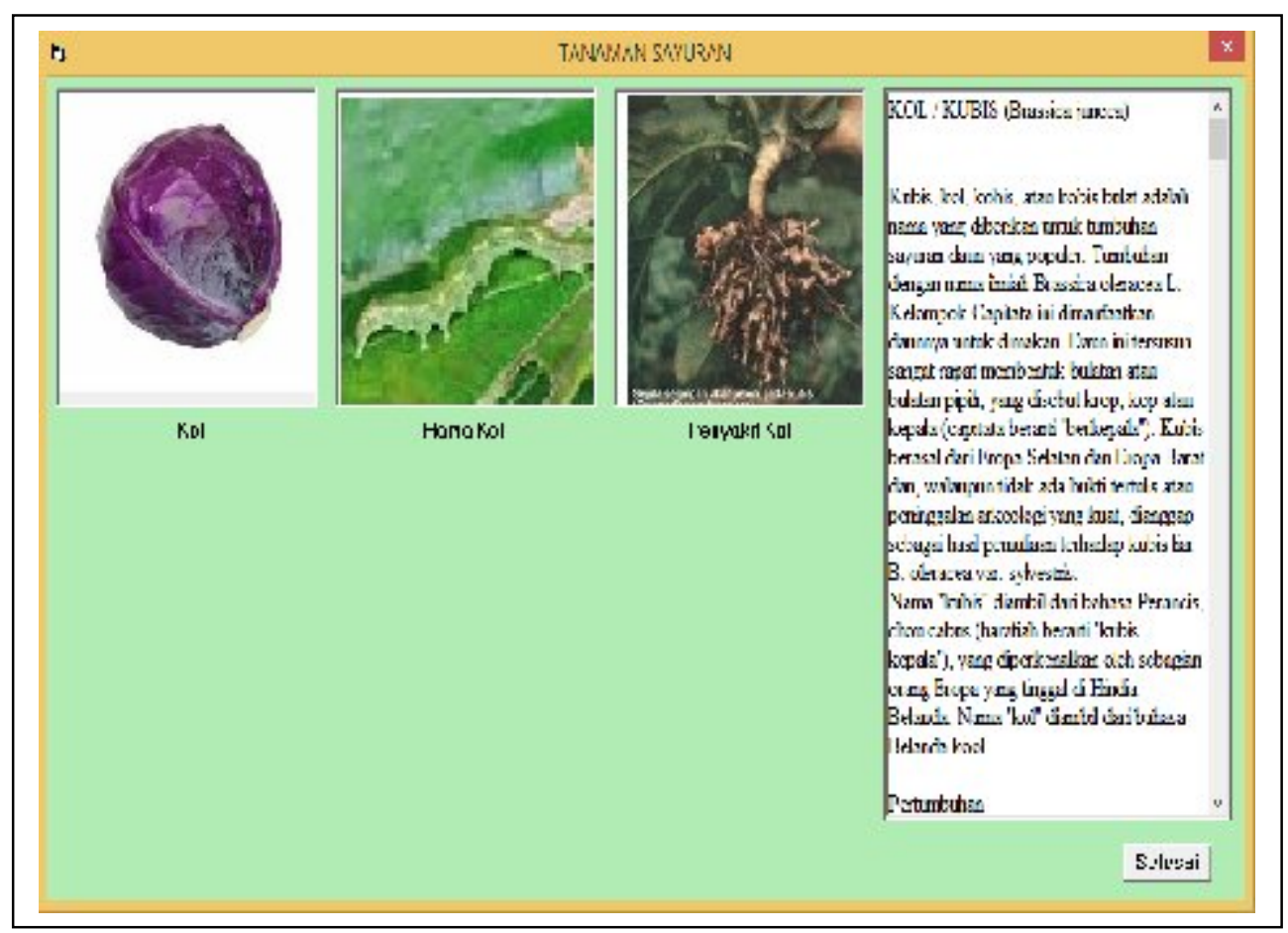

Gambar 4. Tampilan Contoh Informasi Hama dan Penyakit

\section{KESIMPULAN}

Berdasarkan hasil ujicoba program yang sedang dibuat dengan menggunakan data dan informasi yang telah dikumpulkan, dapat disimpulkan bahwa :

a. Program yang sedang dibuat, mudah dalam penggunaannya, karena tidak memerlukan keahlian dan keterampilan khusus dalam menjalankannya.

b. Program ini akan memberikan kemudahan bagi pengguna (penyuluh pertanian dalam membantu berbagai persoalan yang ada pada petani. c. Program yang sedang dibuat mampu memberikan berbagai informasi yang praktis dalam hal jenis tanaman, hama dan penyakit yang ada serta tata cara penanggulangannya.

\section{DAFTAR PUSTAKA}

Andri Kristanto. 2008. Perancangan Sistem Informasi dan Aplikasinya. Penerbit Gava Media. Yogyakarta

Anonim, 2013. Statistik Sumber Daya Manusia Pertanian dan Kelembagaan Petani 2013. Pusat Data dan Sistem Informasi Pertanian. Sekretariat Jenderal Kementrian Pertanian 
Moses, 2004. Konsep Sistem. www.ie.its.ac.id/moses.

Novia, A., 2007. Aplikasi Windows dengan Visual Basic Enterprise. Penerbit. PT. Elekmedia Komputindo. Jakarta.

Novi Dian Nathasia, 2013. Disain Sistem Pakar Identifikasi Penyakit Tanaman Hortikultura Untuk Mempermudah Penanggulangan Hama. Jurnal Teknologi Informasi. Volume 2. Nomor 2 Tahun 2013. http://lkppm. pradnya.ac.id/wpcontent/uploads/2013/03/6.pakar-tanaman-168-180.pdf. Diunduh pada tanggal 24 April 2014.

Pracaya, 2007. Hama dan Penyakit Tanaman. Edisi Revisi. Penerbit : Penebar Swadaya. Jakarta. 434 Halaman.

Rusmawan, U., 2009. Koleksi Program VB 6.0 Konsep ADO.
Penerbit : PT. Elex Media Komputindo. Jakarta.

Sommerville, I., 2001. Software Engineering. $\quad 6^{\text {th }}$ Edition. CPeason education Limited 2001. United Kingdom Alih Bahasa oleh Yuhilza Hanum, 2004. Rekayasa Perangkat Lunak. Editor : HM. Wibi Hardani. Erlangga

Sutanta, E., 2005. Pengantar Teknologi Informasi. Penerbit : Graha Ilmu. Jakarta

Tuswanto, Abdul Fadlil, 2013, Sistem Pakar Untuk Mendiagnosa Hama dan Penyakit Tanaman Bawang Merah Menggunakan Certainty Factor. Jurnal Sarjana Teknik Informatika. Volume 1. Nomor 1. Juni 2013. e-ISSN : 2338 - 5197

Winardi, 2010. Asas Asas Manajemen. Penerbit CV. Mandar Maju. Bandung 